\title{
The Impact of Early Life Stress on the Genetic Influence on Brain and Cognitive Development in Children
}

\author{
Running title: ELS alters the genetic pathway to the brain and cognitive \\ development \\ Hee-Hwan Wang ${ }^{1 *}$, Seo-Yoon Moon ${ }^{2 *}$, Hyun-Jin Kim ${ }^{3}$, KaKyeong Kim ${ }^{1}$, \\ Woo-Young $\mathrm{Ahn}^{3}$, Yoonjung Yoonie $\mathrm{Joo}^{4}$, Jiook $\mathrm{Cha}^{3,5}$ \\ 1. Department of Brain Cognitive and Science, Seoul National University, Seoul, Korea \\ 08825 \\ 2. College of Liberal Studies, Seoul National University, Seoul, Korea 08825 \\ 3. Department of Psychology, Seoul National University, Seoul, Korea 08825 \\ 4. Institute of Data Science, Korea University, Seoul, Korea, 02841 \\ 5. Al Institute, Seoul National University, Seoul, Korea, 08825 \\ ( ${ }^{*}$ denotes equal contribution)
}

Correspondence to:

Yoonjung Yoonie Joo, $\mathrm{PhD}$

201c, International Center for Converging Technology

145 Anam-ro, Seongbuk-gu, Seoul, Republic of Korea, 02841

yoonjungjoo@korea.ac.kr

Office: $+82-2-3290-4646$

Jiook Cha, PhD

Gwanak-ro 1, Building \#16, Suite M512

Gwanak-gu, Seoul, Republic of Korea

connectome@snu.ac.kr

Office: $+82-2-880-8618$

Keywords: genes-brain-cognition, Early Life Stress (ELS), moderated mediation, path modeling, genome-wide polygenic scores (GPS) 
medRxiv preprint doi: https://doi.org/10.1101/2021.12.27.21268445; this version posted December 30, 2021. The copyright holder for this preprint (which was not certified by peer review) is the author/funder, who has granted medRxiv a license to display the preprint in perpetuity.

It is made available under a CC-BY-NC-ND 4.0 International license .

31

32

33

34

35

36

37

38

39

40

4

42

43

44

45

46

47

48

49

50

51

\section{Abstract}

Early life stress (ELS), such as abuse, neglect, and maltreatment, is a well-known risk factor for mental illness. However, it is unclear how ELS affects the brain and cognitive development. Identifying specific relationships of ELS with the genetic and brain-related underpinnings of cognitive development may reveal biological mechanisms responsible for the negative impact of ELS and those that lead to individual differences in sensitivity (or resilience) to ELS. In this study, to investigate the interlinked processes of cognitive development, we analyzed the multimodal data of DNA genotypes, brain imaging (MRI), and neuropsychological assessment (NIH Toolbox) outcomes of 4,276 children (ages 9 to 10 years, European ancestry) from the Adolescent Brain Cognitive Development (ABCD) study. We estimated the genetic influence on cognitive capacity using genome-wide polygenic scores (GPSs). Our regression and mediation analyses revealed significant causal relationships for the gene-brain-cognition pathway: Brain structural development significantly mediated the genetic influence on cognitive development (partial mediation effect $=0.016$, $\left.P_{F W E}<0.001\right)$. Interestingly, within the triangular relationship, we found a significant moderation effect of abuse only on the gene-to-brain pathway (Index of Moderated Mediation $\left.=-0.007 ; 95 \% \mathrm{Cl}=-0.012 \sim-0.002 ; P_{F W E}<0.05\right)$. These findings indicate the negative modulatory effects of ELS on the genetic influence on brain structural development that lead to disadvantageous neurocognitive development in prepubertal children. 


\section{Introduction}

53 Early life stress (ELS), such as abuse and neglect, is a well-known major risk factor

54 for maladaptive cognition, behaviors, and psychiatric disorders $\frac{1-4}{2}$ with long-term sequelae ${ }^{5}$.

55 ELS modulates the expression of the genes responsible for stress physiology, emotion

56 regulation, cognitive control, and learning and memory $\underline{6-9,10}$. Animal literature shows a causal

57 effect of ELS on cognition and behaviors $\frac{11-20}{2}$ and the epi-/genetic mechanisms within the

58 brain $\stackrel{21-24}{=}$. In humans, similar mechanisms may be involved in psychopathology $\frac{25,26}{\text {, stress }}$

59 physiology ${ }^{\underline{7}}$, or emotion regulation $\underline{27-29}$.

60

61 outcomes and brain functional and structural representations $\frac{1.3 .8}{}$, exactly how ELS affects

62 cognitive capacity in humans remains unclear. Moreover, the impact of ELS on the

63 development of the brain and cognition in children remains unknown. Addressing these

64 questions will provide much-needed insight into who, when, and where to intervene

65 regarding the negative neurocognitive outcomes of ELS. Considering the well-known impact

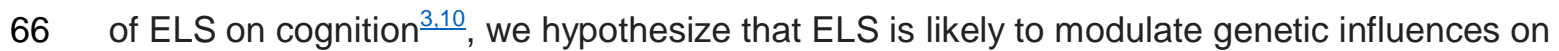

67 brain development as well as cognitive development $\frac{3,5}{}$.

68 Cognitive development involves multiple dynamic processes that are regulated by the 69 complex interplay of genetic and environmental factors ${ }^{30-32}$. Despite its significant impact,

70 however, less is known about the biological mechanisms of how early environmental factors

71 such as ELS, interact with genetic influences and impact cognitive development in children.

72 The recent development of the genome-wide polygenic score approach (GPS) allows

73 individual genetic loadings for cognitive capacity (e.g., accounting for up to $13 \%$ of the

74 variance in cognitive outcomes in adults ${ }^{33}$ ) to be estimated quantitatively. Using this rigorous

75 computational approach, we aimed to test whether ELS modulates the gene-brain-cognition

76 development process. 
medRxiv preprint doi: https://doi.org/10.1101/2021.12.27.21268445; this version posted December 30, 2021. The copyright holder for this preprint (which was not certified by peer review) is the author/funder, who has granted medRxiv a license to display the preprint in perpetuity. It is made available under a CC-BY-NC-ND 4.0 International license . This study had two main questions. First, does a gene-brain-cognition pathway exist during developmental periods? If so, does ELS negatively affect the causal pathway? We investigated these questions using multimodal data, including genetics, brain imaging, psychological data, and cognitive testing in large samples of prepubertal children (ages 9 to 10 years) with a wide range of sociodemographic characteristics. 


\section{Methods}

\section{Study Participants}

study, an ongoing longitudinal multisite study of brain development and health of youth in the

86 United States. We used the deidentified neuroimaging, demographic, genetic, and

87 behavioral data from the ABCD 2.0 Data Release ${ }^{\frac{34}{4}}$, these data were collected across 21

88 sites from 2015 to 2018 . The participants were 11,875 children from the U.S. who were aged

89 9-10 years $\frac{35}{}$. After removing participants who had at least one missing value from genetic,

90 neuroimaging, and ELS data, 4,276 participants were included in our analyses.

\section{Genotype data for Genome-wide polygenic scores (GPS)}

Saliva samples were collected from study participants and were genotyped using the

94 Affymetrix NIDA Smokescreen array (733,293 SNPs) at the Rutgers University Cell and DNA

95 Repository. We removed any inferiorly genotyped SNPs with thresholds of (i) genotype call

rate $<95 \%$, (ii) sample call rate $<95 \%$, and (iii) rare variants with minor allele frequency

$97(\mathrm{MAF})<1 \%$. We imputed the data using the Michigan Imputation Server ${ }^{\frac{36}{6}}$ based on the 1000

98 Genome phase 3 reference panel with Eagle ver2.4 phased output $\frac{37}{3}$. For the imputed

$9912,046,090$ SNPs, we additionally removed data from any individuals with $>5 \%$ missing

100 genotypes; extreme heterozygosity ( $F$ coefficient $>3$ standard deviation from the population

101 mean); and SNPs with $<0.4$ imputation INFO score, $>5 \%$ missingness rate, $<1 \%$ MAF and

102 Hardy-Weinberg equilibrium $\left(p<10^{-6}\right)$. Genetic ancestry was determined with the

103 fastSTRUCTURE algorithm $\frac{38}{}$, available from $A B C D$ release 3.0. Our analysis was restricted

104 to individuals with European ancestry to control for population stratification. We estimated

105 both kinship coefficients (K.C.s) and principal components (P.C.s) to control familial 
medRxiv preprint doi: https://doi.org/10.1101/2021.12.27.21268445; this version posted December 30, 2021. The copyright holder for this preprint (which was not certified by peer review) is the author/funder, who has granted medRxiv a license to display the preprint in perpetuity.

It is made available under a CC-BY-NC-ND 4.0 International license .

106 relatedness and ancestry admixture using PC-Air $\underline{39}$ and PC-Relate $\underline{\underline{40}}$. We selected unrelated

107 samples that were inferred to be more distant than 4th-degree relatives (K.C.>0.022) and

108 removed any genetic outliers that fell significantly outside (>6 S.D. limits) the center in P.C.

109 space. In the rest of this paper, we used genotype data $(11,301,999$ variants $)$ of 8,523

110 unrelated European samples after Q.C., and the first ten ancestrally informative P.C.s were

111 used as covariates in all the reported analyses (Supplementary Figure 1).

112 To assess the subject-level genetic propensity for cognitive ability, we computed

113 genome-wide polygenic scores (GPS) for cognitive performance (CP) and educational

114 attainment (EA) using publicly available GWAS summary statistics based on the European

115 population ${ }^{30}$. The GPSs were constructed using PRSice $2^{41}$, adjusting for the first ten

116 principal components (P.C.s) of the genotype data to control for population stratification.

\section{Brain Imaging-Anatomical Imaging}

T1-weighted (T1w) 3D structural MRI images were acquired in the ABCD study. We processed the images following established protocols $\frac{42,43}{}$ : The gradient nonlinearity distortion correction method was performed on structural MRI scans to improve geometric

122 accuracy and image intensity reproducibility ${ }^{44}$. Based on tissue segmentation and sparse

123 spatial smoothing, intensity nonuniformity was corrected. Then, the data were then

124 resampled with $1 \mathrm{~mm}$ isotropic voxels into rigid alignment with an atlas-derived brain.

125 Cortical surface reconstruction was applied using the following procedures: structural

$126 \mathrm{MRI}$ scans were processed using FreeSurfer v6.0 (https://surfer.nmr.mgh.harvard.edu) for

127 cortical surface reconstruction ${ }^{45}$, which includes skull-stripping ${ }^{46}$, white matter segmentation

128 and initial mesh creation $\frac{45}{}$, correction of topological defects, surface optimization $\frac{47,48}{}$, and nonlinear registration to a spherical surface-based atlas $\underline{49}$. 
medRxiv preprint doi: https://doi.org/10.1101/2021.12.27.21268445; this version posted December 30, 2021. The copyright holder for this preprint (which was not certified by peer review) is the author/funder, who has granted medRxiv a license to display the preprint in perpetuity.

It is made available under a CC-BY-NC-ND 4.0 International license .

130

131

132

133

134

135

136

137

138

139

140

141

142

143

144

145

146

147

148

149

150

151

152

153

154

\section{Brain Imaging-Diffusion Spectrum Imaging}

We used the diffusion spectrum images from the $A B C D$ study that were preprocessed using the following protocol ${ }^{50}$ by the ABCD Data Analysis and Informatics

Center (DAIC). Eddy current distortion correction was used with a nonlinear estimation using diffusion gradient orientations and amplitudes to predict the pattern of distortion ${ }^{51}$. Head motion was corrected by registering images synthesized from tensor fit $\underline{52}$. Diffusion gradients were adjusted for head rotation $\frac{52,53}{}$. To identify and replace dark slices due to abrupt head motion, we used robust diffusion tensor estimation ${ }^{54}$. B0 distortion was corrected with the reversing gradient method $\frac{55}{}$. Gradient nonlinearity distortion correction was applied $\frac{44}{}$. The data were resampled to a standard orientation with an isotropic resolution of $1.5 \mathrm{~mm}$.

To estimate accurate brain imaging phenotypes, we used individual connectome data. We applied MRtrix $3^{\frac{56}{6}}$ for whole-brain white matter tract estimation and individualized connectome generation. For connectivity metrics, we used streamline counts associated with fiber connection strength $\frac{57,58}{}$ associated with fiber integrity. We decreased noise ${ }^{\frac{59}{}}$, and performed bias correction with the Advanced Normalization Tools (ANTs) pipeline's N4 algorithm $^{60}$. To obtain a connectivity index with a white matter pathway $\frac{61}{}$, we performed probabilistic tractography by second-order integration over fiber orientation distributions $\frac{62}{}$, with random seeding across the brain and target streamline counts of 20 million. These initial tractograms were filtered from preliminary tractograms using spherical-deconvolution informed filtering (2:1 ratio). With a final streamline count of 10 million, we generated an $84 x$ 84 whole-brain connectome matrix for each participant using the T1-based parcellation and segmentation in FreeSurfer. This pipeline ensured that individual participants' connectomes were restricted to their own neuroanatomy. We carried out the computation on the supercomputers at Argonne Leadership Computing Facility Theta and Texas Advanced Computing Center Stampede2. 
medRxiv preprint doi: https://doi.org/10.1101/2021.12.27.21268445; this version posted December 30, 2021. The copyright holder for this preprint (which was not certified by peer review) is the author/funder, who has granted medRxiv a license to display the preprint in perpetuity.

It is made available under a CC-BY-NC-ND 4.0 International license .

155 Dimensionality reduction of brain data

156 To extract brain morphometric representations correlated with genetic influence on

157 intelligence, we first performed generalized linear model analysis using cognitive capacity

158 GPSs as independent variables and neuroimaging data as dependent variables adjusted to

159 covariates (e.g., age, sex, maternal education, income, BMI, study site, and marital status).

160 Among three different types of neuroimaging data (structural MRI, DTI-count, and DTI-FA),

161 only brain morphometric features (i.e., structural MRI) showed significant associations with

162 cognitive capacity GPSs ( $P_{F W E}<0.05$; Figure 3, Supplementary Figure 2, Supplementary

163 Table 1$)^{\frac{63}{}}$. We then performed principal component analysis to extract representations from

164 brain morphological features associated with CP GPS or EA GPS (R version 3.4.1). We

165 used the first principal components as representations of the brain.

NIH Toolbox Cognition Battery data

NIH Toolbox Cognitive Function Tests $\underline{\underline{64}}$ were used to assess various levels of

general cognitive ability of the participants. For each child, summary scores from the $\mathrm{NIH}$

170 Toolbox Cognition Battery were provided, including the crystallized intelligence composite

171 score (mainly measuring prior learning and past experiences about language), the fluid

172 intelligence composite score (mainly measuring abstract reasoning and learning ability in

173 novel situations), and total intelligence composite score, which is the combination of both

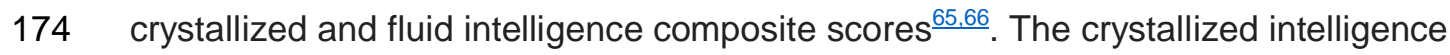

175 composite score is a composite of the Picture Vocabulary Test and the Oral Reading

176 Recognition Test outcomes, and the fluid intelligence composite score is a composite of the

177 Dimensional Change Card Sort Test, the Flanker Inhibitory Control and Attention Test, the

178 Picture Sequence Memory Test, the List Sorting Working Memory Test, and the Pattern 
medRxiv preprint doi: https://doi.org/10.1101/2021.12.27.21268445; this version posted December 30, 2021. The copyright holder for this preprint (which was not certified by peer review) is the author/funder, who has granted medRxiv a license to display the preprint in perpetuity.

It is made available under a CC-BY-NC-ND 4.0 International license .

179 Comparison Processing Speed Test outcomes. Total intelligence composite score is a

180 representation of general intelligence and is an aggregation of all the tests $\frac{67}{}$.

181

182

\section{Early life stress}

We derived ELS measures based on child exposure domains in the ABCD study $\underline{\underline{68}}$

184 (Supplementary Table 2). ELS measures were divided into three main categories:

185 household challenges, neglect, and abuse. Subcategories of ELS data were as follows:

186 parental separation or divorce, criminal household member, household substance abuse,

187 mental illness in household, mother treated violently in household challenges, emotional

188 neglect, physical neglect in neglect; and physical abuse and sexual abuse in abuse. We

189 extracted the items of each subscale from the following various measurement tools

190 (participant- or parent-reported): ABCD Family Environment Scale-Family Conflict Subscale

191 Modified from PhenX, ABCD Diagnostic Interview for DSM-5 Traumatic Events, ABCD

192 Family History Assessment, ABCD Parent Demographics Survey, ABCD Children's Report

193 of Parental Behavioral Inventory, and ABCD Parental Monitoring Survey. We averaged the

194 measurements for each subcategory and transformed them into $z$ scores. The higher the

195 score, the more stressful experiences children had.

\section{Statistical Analysis}

We performed a generalized linear model for three types of relationships - GPS-

brain, GPS-intelligence composite scores, and brain-intelligence composite scores. We

200 included the following covariates into those models: age, sex, maternal education, parental

201 income, BMI, study site, and marital status. Family ID was not included because our analysis

202 was performed in the dataset of unrelated individuals after excluding any relatives fourth- 
medRxiv preprint doi: https://doi.org/10.1101/2021.12.27.21268445; this version posted December 30, 2021. The copyright holder for this preprint (which was not certified by peer review) is the author/funder, who has granted medRxiv a license to display the preprint in perpetuity.

It is made available under a CC-BY-NC-ND 4.0 International license .

203 degree or closer during the genetic QC process. We used familywise error (i.e., Bonferroni

204 correction) in each type of relationship for multiple comparison corrections.

205 For path modeling, we first tested an initial mediation model (Figure 1-a) to check

206 whether the key relationship of the GPS-brain-cognition pathway was significant. Before

207 examining the role of ELS in the GPS-brain-cognition pathway, we tested whether ELS

208 directly affects cognition and whether ELS moderates the gene-cognition pathway (Figure 1-

209 b). After we determined the potential moderation effect of ELS on the GPS-brain-cognition

210 pathway, we evaluated the first-stage moderated mediation models and the second-stage

211 moderated mediation models, following the framework of moderated mediation analysis $\underline{69-71}$.

212 These models assessed how ELS and its interaction with genetics or the brain, would affect

213 the triangular pathway. We repeated the analyses with different subtypes of ELS and

214 compared their effects.

215 Mediation and moderated mediation analyses were performed in R environment

216 v3.4.1 using the lavaan v0.6-7 package with 1000 bootstrapping replicates. Mediation

217 models included the same covariates that were used in the regression model. Parental

218 separation or divorce had to be excluded in a moderated mediation model because of model

219 convergence issues. 
medRxiv preprint doi: https://doi.org/10.1101/2021.12.27.21268445; this version posted December 30, 2021. The copyright holder for this preprint (which was not certified by peer review) is the author/funder, who has granted medRxiv a license to display the preprint in perpetuity.

It is made available under a CC-BY-NC-ND 4.0 International license .

221

222

223

224

225

226

227

228

229

230

231

232

233

234

235

236

237

238

239

240

241

242

243

\section{Results}

\section{Participants}

After quality control, our study cohort comprised 4,276 unrelated children of European ancestry with a mean age of $9-10$ years from the ABCD study ${ }^{35}$. The demographic characteristics of the patients, stratified by records of ELS experience, are summarized in Table 1 (Supplementary Table 3) and Figure 2. All covariates, except for BMI, showed significant differences in experience with one or more type of ELS (abuse: $P<0.001$, neglect: $P<0.05$, and household challenges: $P<0.05)($ Supplementary Table 4).

\section{Correlation among GPS, Brain, and Intelligence}

\section{Cognitive Capacity GPS-Brain}

Out of 992 brain morphometric features, 169 and 44 brain features correlated significantly with CP GPS ( $\left.P_{F W E}<0.05\right)$ and EA GPS, respectively $\left(P_{F W E}<0.05\right)$, when adjusted for age, sex, maternal education, income, BMI, study site, and marital status (Figure 3). Of note, global brain features - including total gray matter volume, total cortex volume, subcortical gray matter volume, and total cerebral white matter volume - were shown to have significant associations with both GPSs (Supplementary Table 1). White matter fiber counts and fractional anisotropy of the structural connectomes showed no significant correlations with either GPS (Supplementary Figure 2). To obtain cognitive capacity GPS-related brain representations, we linearly reduced the dimensionality of brain morphometric features correlated with each GPS by performing principal component analysis. We verified that only the first components substantially explained the variance of each GPS-related brain morphometric feature (Brain CP GPS: 44.5\%; Brain EA GPS: 54.9\%) 
medRxiv preprint doi: https://doi.org/10.1101/2021.12.27.21268445; this version posted December 30, 2021. The copyright holder for this preprint (which was not certified by peer review) is the author/funder, who has granted medRxiv a license to display the preprint in perpetuity.

It is made available under a CC-BY-NC-ND 4.0 International license .

244 (Supplementary Figurea 3, 4, 5) and were significantly correlated with cognitive capacity

245 GPS (Brain CP GPS: $\beta=0.10, P_{F W E}<0.001$; Brain EA GPS: $\beta=0.15, P_{F W E}<0.001$ )

246 (Supplementary Table 5).

Both Brain CP GPS and Brain EA GPS were significantly correlated with all three types

250 of intelligence composite scores $\left(P_{F W E}<0.001\right)$. Among the different types of intelligence

251 composite scores, both brain representations showed the highest effect size on crystallized

252 intelligence composite scores (Brain CP GPS: $\beta=0.18$; Brain EA GPS: $\beta=0.18$ ), with the

253 lowest effect size on fluid intelligence composite scores (Brain CP GPS: $\beta=0.05$; Brain EA

254 GPS: $\beta=0.05)$. Total intelligence composite score was moderately correlated with brain

255 representations (Brain CP GPS: $\beta=0.12$; Brain EA GPS: $\beta=0.12$ ) (Supplementary Table 6).

Both CP and EA GPS were significantly correlated with the outcomes of all three of

259 the different types of intelligence measures $\left(P_{F W E}<0.05\right)$. Test statistics showed that

260 composite scores of crystallized intelligence appeared to have the strongest associations

261 with both GPSs (CP GPS: $\beta=0.17$; EA GPS: $\beta=0.15$ ), followed by total intelligence

composite scores (CP GPS: $\beta=0.14$; EA GPS: $\beta=0.10$ ) and the fluid intelligence 
medRxiv preprint doi: https://doi.org/10.1101/2021.12.27.21268445; this version posted December 30, 2021. The copyright holder for this preprint (which was not certified by peer review) is the author/funder, who has granted medRxiv a license to display the preprint in perpetuity.

It is made available under a CC-BY-NC-ND 4.0 International license .

\section{Mediation Analysis}

266 Our analysis of the GPS-brain-cognition pathway (Figure 1-a) showed that the brain

267 morphometric representations significantly mediated the causal effect of both GPSs on all

268 types of intelligence $\left(P_{F W E}<0.001\right)$. Both GPSs showed the strongest direct effect on

269 crystallized intelligence composite scores ( $\boldsymbol{\beta}$ direct effect of $C P$ GPS $=0.15 ; \boldsymbol{\beta}$ direct effect of EA

270 GPS $=0.13$ ) compared to that on fluid intelligence composite scores ( $\boldsymbol{\beta}$ direct effect of CP GPS

$271=0.09 ; \boldsymbol{\beta}$ direct effect of EA GPS $=0.04)$ and total intelligence composite scores $(\boldsymbol{\beta}$ direct effect

272 of $C P$ GPS $=0.13 ; \boldsymbol{\beta}$ direct effect of EA GPS $=0.09$ ). Both GPSs also showed the strongest

273 indirect effect size on crystallized intelligence composite scores, which were determined by

274 brain morphometric representation ( $\boldsymbol{\beta}_{\text {indirect effect of } C P \text { GPS }}=0.016 ; \quad \boldsymbol{\beta}_{\text {indirect effect of } E A}$

275 GPS $=0.016)$, compared to fluid intelligence composite scores ( $\beta_{\text {indirect }}$ effect of $C P$ GPS $=$

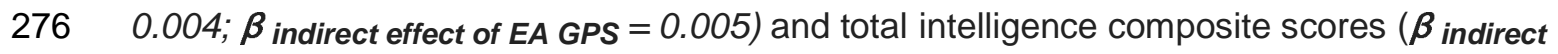

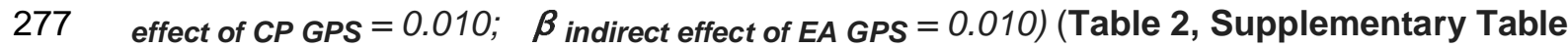

278 7, Figure 4).

Prior to moderated mediation analysis, we first assessed the correlation between

282 ELS and intelligence composite scores and the evaluated the moderation effects of ELS on

283 the relationship between cognitive capacity GPSs and intelligence composite scores (Figure 
medRxiv preprint doi: https://doi.org/10.1101/2021.12.27.21268445; this version posted December 30, 2021. The copyright holder for this preprint (which was not certified by peer review) is the author/funder, who has granted medRxiv a license to display the preprint in perpetuity.

It is made available under a CC-BY-NC-ND 4.0 International license .

284 1-b). Among the different types of ELS, only neglect showed significant correlations with all

285 types of intelligence composite scores (Supplementary Table 8). In moderation analysis, no

286 significant moderation effects of the ELS variables were detected $\left(P_{F W E}>0.05\right)$

287 (Supplementary Table 9).

The following first-stage moderated mediation analysis (Figure 1-c) showed the

289 significant negative moderation effect of abuse on the EA GPS-brain-intelligence composite

290 score relationship. Notably, abuse itself did not affect EA GPS-related brain morphometric

291 representation; however, the interaction between EA GPS and abuse showed a significant

292 negative association with brain morphometric representation $(\boldsymbol{\beta}=-0.04,95 \% \mathrm{Cl}=-0.07 \sim$ -

$\left.2930.014, P_{F W E}<0.05\right)$. Among the different kinds of intelligence composite scores, crystallized

294 intelligence composite scores were the most severely affected by the interplay of ELS and

295 cognitive capacity GPSs through the brain (Index of Moderated Mediation Crystallized

296 Intelligence Score $\left.=-0.007,95 \% \mathrm{Cl}=-0.012 \sim-0.002 ; P_{F W E}<0.05\right)$ compared to the effect on

297 fluid intelligence composite scores (Index of Moderated Mediation Fluid Intelligence Score = -

$\left.2980.002,95 \% \mathrm{Cl}=-0.004 \sim 0.0 ; P_{F W E}<0.01\right)$ and total intelligence composite scores (Index of

299 Moderated Mediation Total Intelligence Score $=-0.005,95 \% \mathrm{Cl}=-0.009 \sim-0.002 ; P_{F W E}<$

300 0.01) (Table 3, Supplementary Table 10). In the second-stage moderated mediation

301 models (Figure 1-d), we found no significant interactions between the brain and ELS on

302 intelligence composite scores (Supplementary Table 11). Taken together, the negative

303 moderation effects of abuse on the causal pathway between genetic and phenotypic

304 intelligence were only observed when the brain served as a mediator. The moderated

305 mediation effect was only significant for abuse, but not for other ELS variables, even in

306 subscales (Supplementary Tables 12, 13). 
medRxiv preprint doi: https://doi.org/10.1101/2021.12.27.21268445; this version posted December 30, 2021. The copyright holder for this preprint (which was not certified by peer review) is the author/funder, who has granted medRxiv a license to display the preprint in perpetuity.

It is made available under a CC-BY-NC-ND 4.0 International license .

\section{Discussion}

310 By leveraging the multimodal genetic, neuroimaging, and cognitive assessment data

311 of 4,267 children of European ancestry, we examined the complex interplay among brain

312 structure and genomic influence on cognitive development and how ELS affects the gene-

313 brain-cognition triad. Our analysis reveals likely causal neurodevelopment pathways under

314 the genetic control of intelligence and ELS modulation. We found that brain structural

315 development partially mediates the genomic contributions to cognitive development in young

316 children. Of note, ELS (abuse) specifically modulates the influence of cognitive capacity

317 GPSs on the brain, this modulatory effect then affects cognition. These results show the

318 potential causal relationships between ELS (abuse) and the genetic pathway for

319 neurocognitive development, accounting for biological how it may lead to cognitive deficits in 320 children

$321 \quad$ Extending the existing literature reporting the influence of genetics on the brain and 322 cognition $\frac{3.72-77}{}$, our study shows a more specific multifactorial model in which brain structural 323 development mediates the genetic impact on cognitive development. Of note, this study

324 shows that the association of the cognitive capacity GPS was only significant with gray

325 matter phenotypes but not with white matter phenotypes. This result may be related to the

326 developmental characteristics observed during preadolescence (9 to 10 years old), i.e.,

327 marked changes in gray matter, followed by relatively greater white matter changes or

328 myelination ${ }^{78}$. Additionally, the brain mediation effect may be widespread involving several

329 brain regions, considering that the brain mediator was the first principal component derived

330 from hundreds of brain morphological features. Future research should examine how genetic

331 influence is linked to longitudinal changes in brain structure over one's lifetime. 
334 finding may account for a potential mechanism of the long-term effect of ELS on cognitive

335 deficits. Note that our brain imaging results shows that ELS modulated the genomic

336 influence on the cortical morphology of the various brain regions responsible for cognition

337 and intelligence. In addition to the literature documenting the impact of ELS on affective

338 processing, stress physiology and the relevant brain system $\frac{3,72-77}{}$, this finding shows that

339 ELS impacts cognitive brain circuitry.

340 Our moderated mediation results support genetic differential susceptibility to ELS.

341 The genetic differential susceptibility model proposes that genetic variations of individuals

342 regulate sensitivity or susceptibility to environmental influences $\frac{79-81}{}$. In our analysis, as a

343 result of the ELS moderation effects on the gene-to-brain pathway, children with the same

344 level of ELS showed different cognitive outcomes depending on the magnitude of the EA

345 GPS. That is, a child with a higher EA GPS showed a greater negative impact of ELS on the

346 cognitive outcome, whereas one with a lower EA GPS showed a smaller negative impact.

347 Perhaps, in the case of individual with a high GPS, ELS may negatively regulate the

348 expression of the genes responsible for the brain and cognitive development (sequentially as

349 supported in our model). Consequently, otherwise, positive effects of high GPSs on cognitive

350 outcomes may be eliminated under the effect of ELS, resulting in lower cognitive outcomes

351 compared with the individuals with high GPSs and no ELS. A crucial outstanding question is

352 whether this modulatory effect of ELS on the cognitive capacity GPS is linked to epigenetics.

353 Animal research shows that ELS induces epigenetic modification in DNA methylation sites

354 that are associated with a wide array of neural events, such as neurotransmitter biosynthesis,

355 neurological system processes, glial cell proliferation, neurogenesis in the hippocampus,

356 neural migration in the cerebral cortex, neuroplasticity, and neurodevelopmental delay $\stackrel{82-84}{ }$;

357 many of these events are critically related to cognitive development. This line of research

358 may allow precise risk stratification and the development of more individualized intervention

359 strategies. 
medRxiv preprint doi: https://doi.org/10.1101/2021.12.27.21268445; this version posted December 30, 2021. The copyright holder for this preprint (which was not certified by peer review) is the author/funder, who has granted medRxiv a license to display the preprint in perpetuity.

It is made available under a CC-BY-NC-ND 4.0 International license .

360 Another novel aspect of this study was the application of the GPS approach, rather

361 than focusing on selected common variants of DNA, which permitted integrative assessment

362 of the polygenic contribution to cognitive development and revealed its impact on the wide

363 array of brain circuits. A recent study reported a similar finding of the association between

364 cognitive capacity GPS and brain volumes in adult samples in the UK Biobank ${ }^{73}$. Our study

365 showed that the gene-brain-cognition relationship manifests as early as preadolescence.

366 Our observations suggested that physical or sexual abuse significantly modulates the

367 "gene-to-brain" path, which then leads to "cognition" but not the "gene-to-cognition" path.

368 This finding is in line with previous ELS studies reporting that physical neglect and abuse

369 negatively impact genetic regulation of brain systems, such as hippocampal glucocorticoid

370 receptors, neurogenesis, and regulation of brain development $\frac{6,7.9 .82}{}$.

371 The direct effect of cognitive capacity GPSs on cognition was tenfold larger in

372 magnitude than the indirect effects on the brain. Note that the gray matter representations

373 derived from ROI-level morphometry may only partially account for the gene-to-brain effects.

374 Indeed, a morphometric analysis may not fully detect subtle changes in the brain tissues

375 under the control of epigenetic (or any other environmental) mechanisms, such as

376 vascularization, neurogenesis, and synaptogenesis. Future research may elucidate sensitive

377 brain representations related to genetic influence and environmental modulation.

378 Another possible explanation of the small indirect effect on the brain may be related

379 to the limitations of linear models in testing complex nonlinear relationships. We used PCA

380 to extract the brain representation (i.e., principal components) from thousands of brain

381 morphometric variables. We used this method for the ease of statistical modeling (mediation

382 analysis); however, since this method uses a linear and orthogonal transformation of data,

383 we admit that this representation might be too simplistic to capture nonlinear relationships

384 among the brain variables. 
medRxiv preprint doi: https://doi.org/10.1101/2021.12.27.21268445; this version posted December 30, 2021. The copyright holder for this preprint (which was not certified by peer review) is the author/funder, who has granted medRxiv a license to display the preprint in perpetuity.

It is made available under a CC-BY-NC-ND 4.0 International license .

385

Our study showed the utility of our multitrait (cognitive performance and educational

386 attainment) genomic approach for revealing the different patterns of genetic influences on

387 the brain and cognition. Years of education (educational attainment, EA) is a widely used

388 proxy for an intelligence phenotype. This is because of its high genetic correlation with

389 intelligence and the ease of assessment compared to an evaluation of cognitive ability that

390 would require behavioral tests (hence, it is unfavorable in large GWASs). For example, the

391 literature shows that EA GPS correlates with cognitive functioning ${ }^{85}$ and the development of 392 behaviors $\stackrel{86}{ }$.

Although both cognitive capacity GPSs showed significant effects on the gene-brain-

394 cognition pathway, only EA GPS showed a significant modulatory effect of ELS on the

395 pathway; CP GPS did not have a notable effect on the pathway. This observed ELS effect

396 on EA GPS may be related to genetic loading not only for cognitive capacity but also for

397 noncognitive skills and traits required for successful education attainment ${ }^{87}$. On the other

398 hand, CP GPS correlated with a greater number of brain morphometric features than EA

399 GPS did. This may reflect that CP GPS represents the genetic influence primarily on

400 biological processes (i.e., brain development) directly linked to cognitive performance, but

401 not so much on noncognitive processes. These points may be used to guide to future

402 studies examining the gene-environment interaction in cognitive development.

403 Our results indicated greater magnitudes of the genetic influence on crystallized

404 intelligence than on fluid intelligence during development. Crystallized intelligence is the

405 ability to apply prior knowledge to problem solving; fluid intelligence is the ability to reason in

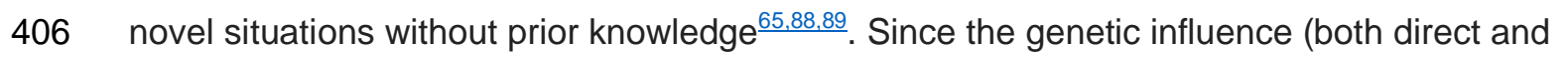

407 indirect) was up to three times larger on crystallized intelligence compared to that on fluid

408 intelligence, the impact of ELS via the gene-brain pathway was proportionally greater on

409 crystallized intelligence than on fluid intelligence. This result adds granularity regarding the

410 specificity of ELS impacts. 
medRxiv preprint doi: https://doi.org/10.1101/2021.12.27.21268445; this version posted December 30, 2021. The copyright holder for this preprint (which was not certified by peer review) is the author/funder, who has granted medRxiv a license to display the preprint in perpetuity.

It is made available under a CC-BY-NC-ND 4.0 International license .

411 A few limitations of the study should be noted. First, it was not within the scope of this

412 study to examine brain function, which is influenced by ELS through the triangular

413 relationship. It is well known that ELS leads to changes in brain function $\frac{3,8}{}$. Previous animal

414 studies support that the function of adaptive gene-brain-cognition feedback systems may be

415 affected by ELS ${ }^{-}$. Thus, the comprehensive impact of ELS on this triangular relationship

416 needs to be further investigated in terms of brain function to reveal all the causal

417 mechanisms. Second, we created composite scores of ELS with several proxy measures

418 instead of using the established measure for childhood trauma, i.e., the Adverse Childhood

419 Experiences (ACE) questionnaire $\frac{90}{}$. This was mainly due to the unavailability of the ACE

420 questionnaire data in the ABCD study. However, it is of note that we included questionnaires

421 similar to those of the ACE questionnaire and included several ELS-related measurements ${ }^{68}$,

422 thus aggregating various adverse environmental factors.

\section{Acknowledgments}

This work was supported by the New Faculty Startup Fund from Seoul National

426 University and a Research grant from Basic Science Research Program through the

427 National Research Foundation of Korea (NRF) funded by the Ministry of Education, South

428 Korea (2021R1I1A1A01054995).

\section{Author contributions}

- Study concept and design: Y.J., J.C.

- Acquisition, analysis, or interpretation of data: Y.J., H.W., S.M., K.K., H.K.

- Drafting of the manuscript: Y.J., H.W., S.M., J.C. 
medRxiv preprint doi: https://doi.org/10.1101/2021.12.27.21268445; this version posted December 30, 2021. The copyright holder for this preprint (which was not certified by peer review) is the author/funder, who has granted medRxiv a license to display the preprint in perpetuity. It is made available under a CC-BY-NC-ND 4.0 International license .

- Critical revision of the manuscript for important intellectual content: Y.J., J.K., H.W. S.M., K.K., W.A.

- Statistical analysis: H.W., S.M.

- Obtained funding: J.C.

438

- $\quad$ Study supervision: Y.J. J.C. 
449 1. Saleh, A. et al. Effects of early life stress on depression, cognitive performance and brain 450 morphology. Psychol. Med. 47, 171-181 (2017).

451 2. Pesonen, A.-K. et al. Cognitive ability and decline after early life stress exposure.

$452 \quad$ Neurobiol. Aging 34, 1674-1679 (2013).

453 3. Pechtel, P. \& Pizzagalli, D. A. Effects of early life stress on cognitive and affective 454 function: an integrated review of human literature. Psychopharmacology 214, 55-70 $455 \quad$ (2011).

456 4. De Bellis, M. D. Developmental traumatology: the psychobiological development of 457 maltreated children and its implications for research, treatment, and policy. Dev.

$458 \quad$ Psychopathol. 13, 539-564 (2001).

459 5. Peña, C. J. et al. Early life stress confers lifelong stress susceptibility in mice via ventral 460 tegmental area OTX2. Science 356, 1185-1188 (2017).

461 6. Niwa, M. et al. Adolescent stress-induced epigenetic control of dopaminergic neurons via 462 glucocorticoids. Science 339, 335-339 (2013).

463 7. Fuge, P. et al. Interaction of Early Life Stress and Corticotropin-Releasing Hormone 464 Receptor Gene: Effects on Working Memory. Biological Psychiatry vol. 76 888-894 465 (2014).

466 8. Chen, Y. \& Baram, T. Z. Toward Understanding How Early-Life Stress Reprograms 467 Cognitive and Emotional Brain Networks. Neuropsychopharmacology 41, 197-206 468 (2016).

469 9. McGowan, P. O. et al. Epigenetic regulation of the glucocorticoid receptor in human 470 brain associates with childhood abuse. Nat. Neurosci. 12, 342-348 (2009). 
medRxiv preprint doi: https://doi.org/10.1101/2021.12.27.21268445; this version posted December 30, 2021. The copyright holder for this preprint (which was not certified by peer review) is the author/funder, who has granted medRxiv a license to display the preprint in perpetuity.

It is made available under a CC-BY-NC-ND 4.0 International license .

471 10. Koenen, K. C., Moffitt, T. E., Caspi, A., Taylor, A. \& Purcell, S. Domestic violence is

472 associated with environmental suppression of IQ in young children. Dev. Psychopathol.

$473 \quad 15,297-311(2003)$.

474 11. Adjimann, T. S., Argañaraz, C. V. \& Soiza-Reilly, M. Serotonin-related rodent models of 475 early-life exposure relevant for neurodevelopmental vulnerability to psychiatric disorders.

$476 \quad$ Transl. Psychiatry 11, 280 (2021).

477 12. Dong, E., Guidotti, A., Zhang, H. \& Pandey, S. C. Prenatal stress leads to chromatin and 478 synaptic remodeling and excessive alcohol intake comorbid with anxiety-like behaviors in 479 adult offspring. Neuropharmacology 140, 76-85 (2018).

480 13. Ivy, A. S. et al. Hippocampal dysfunction and cognitive impairments provoked by chronic 481

482

483

14. Spinelli, S. et al. Early-life stress induces long-term morphologic changes in primate brain. Arch. Gen. Psychiatry 66, 658-665 (2009).

15. Sun, X., Zhang, Y., Li, X., Liu, X. \& Qin, C. Early-Life Neglect Alters Emotional and Cognitive Behavior in a Sex-Dependent Manner and Reduces Glutamatergic Neuronal Excitability in the Prefrontal Cortex. Frontiers in Psychiatry vol. 11 (2021).

16. Bock, J., Riedel, A. \& Braun, K. Differential changes of metabolic brain activity and interregional functional coupling in prefronto-limbic pathways during different stress conditions: functional imaging in freely behaving rodent pups. Front. Cell. Neurosci. 6, 19 (2012).

17. Molet, J. et al. Fragmentation and high entropy of neonatal experience predict adolescent emotional outcome. Transl. Psychiatry 6, e702 (2016). 
medRxiv preprint doi: https://doi.org/10.1101/2021.12.27.21268445; this version posted December 30, 2021. The copyright holder for this preprint (which was not certified by peer review) is the author/funder, who has granted medRxiv a license to display the preprint in perpetuity.

It is made available under a CC-BY-NC-ND 4.0 International license .

496 19. Radley, J. J. et al. Repeated stress alters dendritic spine morphology in the rat medial 497 prefrontal cortex. J. Comp. Neurol. 507, 1141-1150 (2008).

498 20. Aisa, B., Tordera, R., Lasheras, B., Del Río, J. \& Ramírez, M. J. Cognitive impairment 499 associated to HPA axis hyperactivity after maternal separation in rats.

$500 \quad$ Psychoneuroendocrinology vol. 32 256-266 (2007).

501 21. Alviña, K., Jodeiri Farshbaf, M. \& Mondal, A. K. Long term effects of stress on

502 hippocampal function: Emphasis on early life stress paradigms and potential involvement

503 of neuropeptide Y. J. Neurosci. Res. 99, 57-66 (2021).

504 22. Kronman, H. et al. Long-term behavioral and cell-type-specific molecular effects of early

505 life stress are mediated by H3K79me2 dynamics in medium spiny neurons. Nat.

$506 \quad$ Neurosci. 24, 667-676 (2021).

507 23. Arabadzisz, D. et al. Primate early life stress leads to long-term mild hippocampal

508 decreases in corticosteroid receptor expression. Biol. Psychiatry 67, 1106-1109 (2010).

509 24. Wang, X.-D. et al. Forebrain CRF1 Modulates Early-Life Stress-Programmed Cognitive

510 Deficits. Journal of Neuroscience vol. 31 13625-13634 (2011).

511 25. De Bellis, M. D. et al. Brain structures in pediatric maltreatment-related posttraumatic

512 stress disorder: a sociodemographically matched study. Biol. Psychiatry 52, 1066-1078

513 (2002).

514 26. Jackowski, A. P. et al. Corpus callosum in maltreated children with posttraumatic stress

515 disorder: a diffusion tensor imaging study. Psychiatry Res. 162, 256-261 (2008).

516 27. Gatt, J. M. et al. Interactions between BDNF Val66Met polymorphism and early life

517 stress predict brain and arousal pathways to syndromal depression and anxiety. Mol.

$518 \quad$ Psychiatry 14, 681-695 (2009).

519 28. Caspi, A. et al. Influence of life stress on depression: moderation by a polymorphism in 520 the 5-HTT gene. Science 301, 386-389 (2003). 
medRxiv preprint doi: https://doi.org/10.1101/2021.12.27.21268445; this version posted December 30, 2021. The copyright holder for this preprint (which was not certified by peer review) is the author/funder, who has granted medRxiv a license to display the preprint in perpetuity.

It is made available under a CC-BY-NC-ND 4.0 International license .

521 29. McLaughlin, K. A. et al. Maltreatment Exposure, Brain Structure, and Fear Conditioning 522 in Children and Adolescents. Neuropsychopharmacology 41, 1956-1964 (2016).

523 30. Lee, J. J. et al. Gene discovery and polygenic prediction from a genome-wide

524 association study of educational attainment in 1.1 million individuals. Nat. Genet. 50,

$525 \quad 1112-1121(2018)$.

526 31. van der Sluis, S., Willemsen, G., de Geus, E. J. C., Boomsma, D. I. \& Posthuma, D.

527 Gene-environment interaction in adults' IQ scores: measures of past and present

528 environment. Behav. Genet. 38, 348-360 (2008).

529 32. Harden, K. P., Turkheimer, E. \& Loehlin, J. C. Genotype by environment interaction in

530 adolescents' cognitive aptitude. Behav. Genet. 37, 273-283 (2007).

531 33. Plomin, R. \& von Stumm, S. The new genetics of intelligence. Nat. Rev. Genet. 19, 148$532159(2018)$.

533 34. Jernigan, T. \& Jernigan, T. Adolescent brain cognitive development study (ABCD) -

$534 \quad$ annual release 2.0. (2019) doi:10.15154/1503209.

535 35. Karcher, N. R. \& Barch, D. M. The ABCD study: understanding the development of risk

536 for mental and physical health outcomes. Neuropsychopharmacology 46, 131-142

$537 \quad$ (2021).

538 36. Das, S. et al. Next-generation genotype imputation service and methods. Nat. Genet. 48, $539 \quad$ 1284-1287 (2016).

540 37. Loh, P.-R. et al. Reference-based phasing using the Haplotype Reference Consortium

541 panel. Nature Genetics vol. 48 1443-1448 (2016).

542 38. Raj, A., Stephens, M. \& Pritchard, J. K. fastSTRUCTURE: variational inference of 543 population structure in large SNP data sets. Genetics 197, 573-589 (2014). 
medRxiv preprint doi: https://doi.org/10.1101/2021.12.27.21268445; this version posted December 30, 2021. The copyright holder for this preprint (which was not certified by peer review) is the author/funder, who has granted medRxiv a license to display the preprint in perpetuity.

It is made available under a CC-BY-NC-ND 4.0 International license .

544 39. Conomos, M. P., Miller, M. B. \& Thornton, T. A. Robust inference of population structure

545 for ancestry prediction and correction of stratification in the presence of relatedness.

$546 \quad$ Genet. Epidemiol. 39, 276-293 (2015).

547 40. Conomos, M. P., Reiner, A. P., Weir, B. S. \& Thornton, T. A. Model-free Estimation of

548 Recent Genetic Relatedness. Am. J. Hum. Genet. 98, 127-148 (2016).

549 41. Choi, S. W. \& O'Reilly, P. F. PRSice-2: Polygenic Risk Score software for biobank-scale

550 data. Gigascience 8, (2019).

551 42. Garavan, H. et al. Recruiting the ABCD sample: Design considerations and procedures.

552 Developmental Cognitive Neuroscience vol. 32 16-22 (2018).

553 43. Casey, B. J. et al. The Adolescent Brain Cognitive Development (ABCD) study: Imaging

554 acquisition across 21 sites. Developmental Cognitive Neuroscience vol. 32 43-54 (2018).

555 44. Jovicich, J. et al. Reliability in multi-site structural MRI studies: effects of gradient non-

$556 \quad$ linearity correction on phantom and human data. Neuroimage 30, 436-443 (2006).

557 45. Dale, A. M., Fischl, B. \& Sereno, M. I. Cortical surface-based analysis. I. Segmentation

558 and surface reconstruction. Neuroimage 9, 179-194 (1999).

559 46. Ségonne, F. et al. A hybrid approach to the skull stripping problem in MRI. Neuroimage

$560 \quad 22,1060-1075$ (2004).

561 47. Fischl, B., Liu, A. \& Dale, A. M. Automated manifold surgery: constructing geometrically

562 accurate and topologically correct models of the human cerebral cortex. IEEE Trans.

$563 \quad$ Med. Imaging 20, 70-80 (2001).

564 48. Ségonne, F., Pacheco, J. \& Fischl, B. Geometrically accurate topology-correction of 565 cortical surfaces using nonseparating loops. IEEE Trans. Med. Imaging 26, 518-529 $566 \quad$ (2007). 
medRxiv preprint doi: https://doi.org/10.1101/2021.12.27.21268445; this version posted December 30, 2021. The copyright holder for this preprint (which was not certified by peer review) is the author/funder, who has granted medRxiv a license to display the preprint in perpetuity.

It is made available under a CC-BY-NC-ND 4.0 International license .

567 49. Fischl, B., Sereno, M. I., Tootell, R. B. H. \& Dale, A. M. High-resolution intersubject

568 averaging and a coordinate system for the cortical surface. Human Brain Mapping vol. 8

$569 \quad 272-284(1999)$.

570 50. Hagler, D. J., Jr et al. Image processing and analysis methods for the Adolescent Brain

571 Cognitive Development Study. Neuroimage 202, 116091 (2019).

57251. Zhuang, J. et al. Correction of eddy-current distortions in diffusion tensor images using

573 the known directions and strengths of diffusion gradients. J. Magn. Reson. Imaging 24,

$574 \quad 1188-1193(2006)$.

575 52. Hagler, D. J. et al. Automated white-matter tractography using a probabilistic diffusion

576 tensor atlas: Application to temporal lobe epilepsy. Human Brain Mapping vol. 30 1535-

$577 \quad 1547$ (2009).

578 53. Leemans, A. \& Jones, D. K. TheB-matrix must be rotated when correcting for subject

579 motion in DTI data. Magnetic Resonance in Medicine vol. 61 1336-1349 (2009).

580 54. Chang, L.-C., Jones, D. K. \& Pierpaoli, C. RESTORE: robust estimation of tensors by

$581 \quad$ outlier rejection. Magn. Reson. Med. 53, 1088-1095 (2005).

582 55. Holland, D., Kuperman, J. M. \& Dale, A. M. Efficient correction of inhomogeneous static

583 magnetic field-induced distortion in Echo Planar Imaging. Neuroimage 50, 175-183

$584 \quad$ (2010).

585 56. Tournier, J.-D. et al. MRtrix3: A fast, flexible and open software framework for medical

$586 \quad$ image processing and visualisation. Neuroimage 202, 116137 (2019).

587 57. Cha, J. et al. Abnormal reward circuitry in anorexia nervosa: A longitudinal, multimodal

$588 \quad$ MRI study. Hum. Brain Mapp. 37, 3835-3846 (2016).

589 58. Cha, J. et al. Neural Correlates of Aggression in Medication-Naive Children with ADHD:

590 Multivariate Analysis of Morphometry and Tractography. Neuropsychopharmacology 40,

$591 \quad 1717-1725(2015)$. 
medRxiv preprint doi: https://doi.org/10.1101/2021.12.27.21268445; this version posted December 30, 2021. The copyright holder for this preprint (which was not certified by peer review) is the author/funder, who has granted medRxiv a license to display the preprint in perpetuity.

It is made available under a CC-BY-NC-ND 4.0 International license .

592 59. Veraart, J. et al. Denoising of diffusion MRI using random matrix theory. Neurolmage vol. $593 \quad 142394-406(2016)$.

594 60. Tustison, N. J. et al. N4ITK: improved N3 bias correction. IEEE Trans. Med. Imaging 29, $595 \quad 1310-1320(2010)$.

596 61. Ciccarelli, O. et al. Probabilistic diffusion tractography: a potential tool to assess the rate 597 of disease progression in amyotrophic lateral sclerosis. Brain 129, 1859-1871 (2006).

598 62. Calamante, F., Tournier, J.-D., Jackson, G. D. \& Connelly, A. Track-density imaging 599 (TDI): super-resolution white matter imaging using whole-brain track-density mapping. $600 \quad$ Neuroimage 53, 1233-1243 (2010).

601 63. Bedre, R. reneshbedre/bioinfokit: Bioinformatics data analysis and visualization toolkit. $602 \quad$ (2021) doi:10.5281/zenodo.4422035.

603 64. Gershon, R. C. et al. NIH toolbox for assessment of neurological and behavioral function. $604 \quad$ Neurology 80, S2-6 (2013).

605 65. Cattell, R. B. Theory of fluid and crystallized intelligence: A critical experiment. Journal of $606 \quad$ Educational Psychology vol. 54 1-22 (1963).

607 66. Weintraub, S. et al. Cognition assessment using the NIH Toolbox. Neurology 80, S54-64 $608 \quad$ (2013).

609 67. Akshoomoff, N. et al. VIII. NIH Toolbox Cognition Battery (CB): composite scores of 610 crystallized, fluid, and overall cognition. Monogr. Soc. Res. Child Dev. 78, 119-132 $611 \quad$ (2013).

612 68. Hoffman, E. A. et al. Stress exposures, neurodevelopment and health measures in the 613 ABCD study. Neurobiology of Stress vol. 10100157 (2019).

614 69. Edwards, J. R. \& Lambert, L. S. Methods for integrating moderation and mediation: a 615 general analytical framework using moderated path analysis. Psychol. Methods 12, 1-22 $616 \quad$ (2007). 
medRxiv preprint doi: https://doi.org/10.1101/2021.12.27.21268445; this version posted December 30, 2021. The copyright holder for this preprint (which was not certified by peer review) is the author/funder, who has granted medRxiv a license to display the preprint in perpetuity.

It is made available under a CC-BY-NC-ND 4.0 International license .

617 70. Hayes, A. F. An Index and Test of Linear Moderated Mediation. Multivariate Behav. Res.

$618 \quad 50,1-22(2015)$.

619 71. Preacher, K. J., Rucker, D. D. \& Hayes, A. F. Addressing Moderated Mediation

620 Hypotheses: Theory, Methods, and Prescriptions. Multivariate Behav. Res. 42, 185-227

$621 \quad$ (2007).

622 72. Thompson, P. M. et al. Genetic influences on brain structure. Nat. Neurosci. 4, 1253-

$6231258(2001)$.

624 73. Elliott, M. L. et al. A Polygenic Score for Higher Educational Attainment is Associated

625 with Larger Brains. Cereb. Cortex 29, 3496-3504 (2019).

626 74. Mitchell, B. L. et al. Educational attainment polygenic scores are associated with cortical

627 total surface area and regions important for language and memory. Neuroimage 212,

$628 \quad 116691(2020)$.

629 75. Posthuma, D. et al. The association between brain volume and intelligence is of genetic 630 origin. Nature neuroscience vol. 5 83-84 (2002).

631 76. Pol, H. E. H. et al. Genetic Contributions to Human Brain Morphology and Intelligence.

632 Journal of Neuroscience vol. 26 10235-10242 (2006).

633 77. van Leeuwen, M. et al. A genetic analysis of brain volumes and IQ in children.

$634 \quad$ Intelligence vol. 37 181-191 (2009).

635 78. Gogtay, N. et al. Dynamic mapping of human cortical development during childhood

636 through early adulthood. Proc. Natl. Acad. Sci. U. S. A. 101, 8174-8179 (2004).

637 79. Belsky, J. Variation in Susceptibility to Environmental Influence: An Evolutionary

638 Argument. Psychological Inquiry vol. 8 182-186 (1997).

639 80. Boyce, W. T. \& Ellis, B. J. Biological sensitivity to context: I. An evolutionary-

640 developmental theory of the origins and functions of stress reactivity. Dev. Psychopathol.

$641 \quad 17,271-301$ (2005). 
medRxiv preprint doi: https://doi.org/10.1101/2021.12.27.21268445; this version posted December 30, 2021. The copyright holder for this preprint (which was not certified by peer review) is the author/funder, who has granted medRxiv a license to display the preprint in perpetuity.

It is made available under a CC-BY-NC-ND 4.0 International license .

642 81. Silveira, P. P. et al. Genetic Differential Susceptibility to Socioeconomic Status and

643 Childhood Obesogenic Behavior: Why Targeted Prevention May Be the Best Societal

644 Investment. JAMA Pediatr. 170, 359-364 (2016).

645 82. Cecil, C. A. M. et al. Epigenetic signatures of childhood abuse and neglect: Implications

646 for psychiatric vulnerability. J. Psychiatr. Res. 83, 184-194 (2016).

647 83. Yang, B.-Z. et al. Child abuse and epigenetic mechanisms of disease risk. Am. J. Prev.

$648 \quad$ Med. 44, 101-107 (2013).

649 84. Labonté, B. et al. Genome-wide epigenetic regulation by early-life trauma. Arch. Gen.

$650 \quad$ Psychiatry 69, 722-731 (2012).

651 85. Rietveld, C. A. et al. GWAS of 126,559 individuals identifies genetic variants associated 652 with educational attainment. Science 340, 1467-1471 (2013).

653 86. Belsky, D. W. et al. The Genetics of Success: How Single-Nucleotide Polymorphisms 654 Associated With Educational Attainment Relate to Life-Course Development. Psychol. 655 Sci. 27, 957-972 (2016).

656 87. Demange, P. A. et al. Investigating the genetic architecture of noncognitive skills using 657 GWAS-by-subtraction. Nat. Genet. 53, 35-44 (2021).

658 88. Merrifield, P. R. \& Cattell, R. B. Abilities: Their Structure, Growth, and Action. American $659 \quad$ Educational Research Journal vol. 12516 (1975).

660 89. Christoforou, A. et al. GWAS-based pathway analysis differentiates between fluid and 661 crystallized intelligence. Genes Brain Behav. 13, 663-674 (2014).

662 90. Felitti, V. J. et al. Relationship of childhood abuse and household dysfunction to many of 663 the leading causes of death in adults. The Adverse Childhood Experiences (ACE) Study. $664 \quad$ Am. J. Prev. Med. 14, 245-258 (1998). 
wi

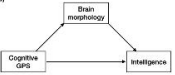

|at

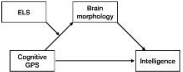

(b)

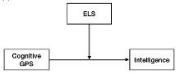

$(0)$

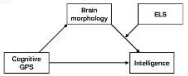

Figure 1. Schematic overview of the tested path models. (a) The baseline m ediation model has the brain factor as a mediator. (b) The moderation model has ELS a s a moderator. (c) The first-stage moderated mediation model for testing the moderafing role of ELS on the relationship between the brain and genomic factors. (c) The secondstage moderated medation model for testing the moderating role of ELS on the relaton ship between the brain and intelligence compos ite scores. 


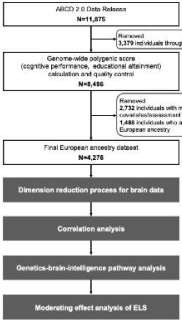

Figure 2. Flow chart of data selection and research design. From the ABCD 2.0 Data release, genetic, brain imaging, and cognitive assessment data for 11,875 parti cipants were collected. For the 8,498 indivduals after initial quality control and GPS cal culaton, we additionally removed samples of non-European ancestry or with any missin g values, for a total of 4,276 participants included in the analysis. 
(a)

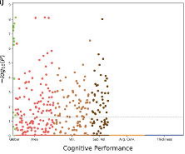

(b)

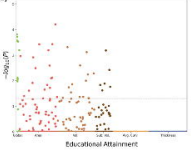

Figure 3. Manhattan pl ots of GPStbrain linear regression. The results of gen eralized Inear models between crain morphometic features and (a) CP GPS and (b) be tween brain morphometnc features and EA GPS are presented using the Bonferronl-cor rected $p$ values. The dotted line indicates the signifcance threshold $\left(P_{F W E}=0.05\right)$. The $X$-axis is the category of brain features: global features (Glocal), brain cortical area (Are a), cortical volume (Volume), subcortical volume (Sub. Vol.), average cortica curvature (Avg. Curv.), and cortical thickness (Thickness). 

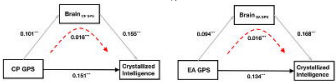

- Dinct Fthod

- - otima enwea

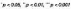

Figure 4. Path diagrams for crystallized intelligence mediation models. Standardized regression coefficientafor each path. Rad dotted lines indicate the total indirect effect. 

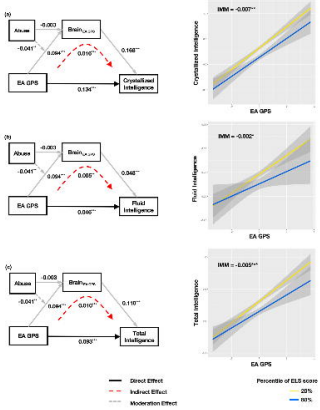

$$
\begin{aligned}
& \text { Percontle of EIS sorme } \\
& \begin{array}{r}
23 \\
-\quad M \%
\end{array} \\
& \text { a }-005-a=0.61-6=0.00
\end{aligned}
$$

Figure 5. Effect of abuse on the EA GPS-brain-cognition pathway. The left panel shows standardized regress -ion coefficients for each path. Red dotted lines indicate the total indiroct effect. Gray dotted lines indicate the moceration effect of ELS on the GPS-brain relationship. The right panel shows differences in the indirect impact caused by composite ELS scores (transparent gray areas indicate confidence intervals ). 
Table1. Dernographic cheracteristics of participents with Europeen ancestry $(\mathrm{N}=4,276)$.

The total participents are divided into five intervals regarding the composite score of ELS.

\begin{tabular}{|c|c|c|c|c|c|}
\hline$S \propto x$ & Number of subjact: & & & & \\
\hline male & 2,271 & & & & \\
\hline famale & $2, \cos$ & & & & \\
\hline fae & Mear & Standard cesation & & & \\
\hline & 119.28 & $7.3 \mathrm{~B}$ & & & \\
\hline EL5 score & $\begin{array}{l}0.2046 \\
\text { (favele) }\end{array}$ & $\begin{array}{l}20-4086 \\
\text { ferracs }\end{array}$ & $\begin{array}{l}10-60 x \\
\text { (íandel }\end{array}$ & $\begin{array}{l}\text { 6O-nDS6 } \\
\text { (Iemale) }\end{array}$ & $\begin{array}{l}\text { ao-100x } \\
\text { (fornale) }\end{array}$ \\
\hline $\begin{array}{l}\text { Household } \\
\text { Chalienees }\end{array}$ & $3 J 11\langle 46 \pi \%$ & $.464148 .7 \%$ & 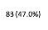 & $15|10.056\rangle$ & $2 \mid 50.059]$ \\
\hline Neglest & 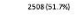 & $1803[41.0 \%)$ & $377(34.2 \%)$ & $81|10.7 \%\rangle$ & $5|39.98|$ \\
\hline Abuse & $4733(46.94)$ & $27(55.6 \%)$ & 1 11000\%s & $0\{0 ;$ & $33 \mid 30.86$ \\
\hline
\end{tabular}




\section{Table 2. Results of mediation analysis}

\begin{tabular}{|c|c|c|c|c|c|c|}
\hline \multirow[t]{2}{*}{ Iixedipenvetspe } & \multicolumn{2}{|c|}{$\begin{array}{l}\text { Crystalized } \\
\text { Irteligeron }\end{array}$} & \multicolumn{2}{|c|}{$\begin{array}{l}\text { Fud } \\
\text { intalignex }\end{array}$} & \multicolumn{2}{|c|}{$\begin{array}{l}\text { Toid } \\
\text { vieligaree }\end{array}$} \\
\hline & प्OPES & EAEFS & cass & EXEPS & CPGFS & EAGTS \\
\hline \multicolumn{7}{|l|}{$\begin{array}{l}\text { cosfitiuni } \\
\text { [95:0] }\end{array}$} \\
\hline$n \rightarrow m$ & $\begin{array}{c}0.101= \\
\text { [0.07a.0.12a }\end{array}$ & $\begin{array}{c}\cos 4^{-1} \\
(1.16,0.222)\end{array}$ & $\begin{array}{c}0.101^{* 1} \\
|00061.23|\end{array}$ & $\begin{array}{c}\text { D.ani"m } \\
{[0.360,0.24]}\end{array}$ & $\begin{array}{c}0.10 \mathrm{n}= \\
{[0.07,0.12 \pi)}\end{array}$ & $\begin{array}{c}12014= \\
00530.22]\end{array}$ \\
\hline$N \rightarrow Y$ & $\begin{array}{c}0.155^{+*} \\
\text { [0.326.917 }\end{array}$ & $\begin{array}{c}0.168^{*+} \\
{[9.1300106]}\end{array}$ & 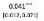 & $\frac{0.050^{\circ}}{\cos }$ & $\begin{array}{c}0.000^{-1} \\
1007.0 .17\end{array}$ & 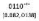 \\
\hline $\begin{array}{l}S \rightarrow N \rightarrow Y \\
\text { drxfres:) }\end{array}$ & $\begin{array}{c}0.43 F^{m} \\
{[0.0 \pi, c c 2]}\end{array}$ & $\begin{array}{c}\text { 0.015=" } \\
\text { (1.s110001 }\end{array}$ & $\begin{array}{c}\text { screse } \\
\text { ocots. }\end{array}$ & $\begin{array}{c}\text { arac" } \\
0.3020001\end{array}$ & $\begin{array}{c}\text { conver } \\
10000.0 .024\end{array}$ & $\begin{array}{l}\text { Data" } \\
\text { nomzogal }\end{array}$ \\
\hline $\begin{array}{r}x \rightarrow \gamma \\
\text { (Drse) }\end{array}$ & 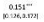 & $\begin{array}{c}0.194^{4+} \\
{[2,197,0,16 Z)}\end{array}$ & $\begin{array}{c}0.00 T^{4.4} \\
\text { posts.tal }\end{array}$ & 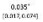 & $\begin{array}{c}0.130^{-4} \\
{[015,0.160]}\end{array}$ & $\begin{array}{c}0052^{--} \\
\text {not2a n8] }\end{array}$ \\
\hline \multicolumn{7}{|l|}{$\mathbf{R}^{2}$} \\
\hline$x \rightarrow w$ & D. 30 & 0269 & $0.2 a \mathrm{E}$ & D.27y & a2kt & $D x+y$ \\
\hline$x \rightarrow Y$ & 0.28 & 0243 & 0.147 & 0.140 & 0248 & 0.250 \\
\hline
\end{tabular}

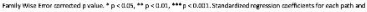

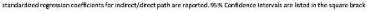

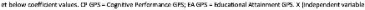

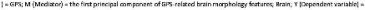

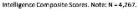


Table 3. Moderated Mediation effect of Abusc on Educational Attainment GPS-BrainCognition

\begin{tabular}{|c|c|c|c|}
\hline Irtel Ipen:s & $\begin{array}{l}\text { Cryetelizes } \\
\text { inculisyes }\end{array}$ & $\begin{array}{l}\text { Hud } \\
\text { iriml pouth }\end{array}$ & $\begin{array}{l}\text { Total } \\
\text { Iolvigatu }\end{array}$ \\
\hline \multicolumn{4}{|l|}{$\begin{array}{l}\text { icentiost } \\
5 \leqslant>0)\end{array}$} \\
\hline$x \rightarrow M$ & 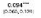 & 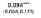 & $\begin{array}{c}0.054= \\
\ln 20410170 \mid\end{array}$ \\
\hline$w \rightarrow w$ & $\begin{array}{l}0033 \\
1412003\end{array}$ & 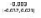 & borat fom: \\
\hline$x^{2} W \rightarrow M$ & $\begin{array}{l}0.042^{2} \\
1,005.5 \times 1\end{array}$ & 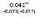 & $\begin{array}{c}\text { OCd! } \\
\text { Inme, neA }\end{array}$ \\
\hline$M \rightarrow x$ & 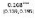 & 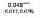 & ${ }_{\mid \mathrm{n} n}^{0150^{-4}}$ \\
\hline$x \rightarrow m+$ rilndienti & $\underset{1 \rightarrow-1}{00-\infty}$ & 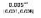 & 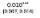 \\
\hline$\underset{x \rightarrow x}{x \rightarrow x^{\prime}}$ & $\frac{0.21 x^{\circ}}{10 \mathrm{~m} 5}$ & $\begin{array}{l}\operatorname{mon} 26^{-4} \\
\min / 4 y_{4}\end{array}$ & $\begin{array}{l}\text { D.degia } \\
\text { |arkx aval }\end{array}$ \\
\hline inden o Moterated & $\begin{array}{c}0.607^{-} \\
1 \times 12500\end{array}$ & $\begin{array}{l}\text { angis } \\
\text { arnien }\end{array}$ & 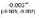 \\
\hline \multicolumn{4}{|l|}{2} \\
\hline$x \in w \rightarrow m$ & 0.282 & 023: & 0281 \\
\hline$x \rightarrow 0$ & 0.241 & $0.2+0$ & 0236 \\
\hline \multicolumn{4}{|c|}{ 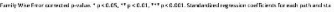 } \\
\hline \multicolumn{4}{|c|}{ 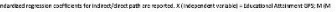 } \\
\hline \multicolumn{4}{|c|}{ 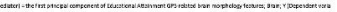 } \\
\hline \multicolumn{4}{|c|}{ 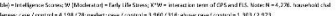 } \\
\hline
\end{tabular}

